\title{
The Susceptibility of Islamic Banks' Credit Risk Towards Macroeconomic Variables
}

\author{
Nursechafia ${ }^{\mathrm{a}}$, Muhamad Abduh ${ }^{\mathrm{b}}$ \\ ${ }^{a}$ Department of Economics \\ Kulliyah of Economics and Management Sciences \\ ${ }^{b}$ IIUM Institute of Islamic Banking and Finance (IIiBF) \\ International Islamic University Malaysia
}

\begin{abstract}
Credit risk is the most anticipated risk in the banking system. It is one of the key elements to assess systemic risk and stress testing financial fragility which is very helpful to come up with macro-prudential surveillance in financial systems. Unlike the conventional banking system, there is dearth of empirical study on macro-credit risk in relation with Islamic banking. As such, further research regarding the stability of the Islamic banking industry has become imperative. Accordingly, this paper is aimed at determining and assessing the long run vulnerabilities of Islamic financing sustainability in term of its response to changes in key macroeconomic variables by using time series econometric approaches of cointegration and vector autoregression (VAR). Based on the result of simulating variance decomposition (VD) and impulse response function (IRF), it is found that, sufficient evidence of long-run relationship between credit risk ratio in Islamic banking industry and the selected macroeconomic variables exist. The exchange rate, supply side-inflation, and growth have been indicated to negatively influence credit risk rate in Islamic banking, while money supply and Islamic interbank money market rate positively affect the risk rate.
\end{abstract}

(c) 2014 IIUM Institute of Islamic Banking and Finance.

Keywords: Islamic banking, credit risk, macro-prudential surveillance, VAR

\section{Introduction}

The systemic crisis that rocked financial sectors in Southeast Asia in 1997 has provided evidence of the presence of a strong relationship between macroeconomic and banking stability. The extent of damages in the financial market in Indonesia in the late 1990s had shown that macroeconomic instability tremendously lead to banking crisis. The crisis that started with the deep depression in Thailand currency Baht in June 1997 later expanded to Indonesia which significantly shoots up inflation to an unprecedented rate of 77.6 percent in the following year (Bank Indonesia, 1999). Consequently, most of the banks that were considered sound got bankrupt due to adverse macroeconomic shocks.

This systemic banking crisis resulted to at least two consequences. Firstly, high cost effect due to the role of central bank as the lender of last resort. To restructure and keep some banks in operation, injection of liquidity estimated at more than 50 percent of GDP was carried out in 1998. Secondly, most of the banks could not effectively carry out their intermediation functions. Addressing instability in the banking sector therefore becomes priority for the stakeholders. This is probably due to the perceived parallel linkages growth between the economy and the banking system in Indonesia.

One of the performance indicators use to measure the stability level of banking is non-performing loans (NPL) for conventional banks or non performing financings (NPF) for Islamic banks. The ratio of NPL or NPF measures bank's stability based on the productive asset quality owned by the bank. High level of this ratio could be translated to potential banking instability. Indeed, the argument advanced here is similar to that of Bracons, et al. (2006) who indicated that the probability of credit default is a key element to consider when analyzing the financial susceptibility and macro-prudential surveillance. 
Default occurs when the debtors are unable to meet their contractual obligations because of because of factor such as economy downturn. A good example is the 1998 economic crisis during which both conventional banks and Islamic banks in Indonesia witnessed an unprecedented high credit default ratios estimated at 58.7 percent and 65.61 percent respectively (Bank Indonesia, 1999). Unlike the conventional banking, the Islamic banking system witnessed rapid growth. For instance, the performance in term of the quality of the assets represented by NPF is reported to be below 5 percent (Bank Indonesia, 2012). Nonetheless, the fundamental philosophy of conventional and Islamic banking is basically different, Islamic banks however have similar risks with its conventional counterpart based on the fact that, both systems operate within the same macroeconomic environment.

As an institution that plays a crucial role in supporting the economy of the country, the banking system reflects the condition of the country's economy as a whole. If the economy is heading towards recession or stagnation, there is high potential for the banks to have their performance nose-dive. This could be due to macroeconomic conditions and the credit default ratio indicators which had its toll on the performance of banking. Moreover, banks play a great role in ensuring smooth financial system through their role in allocating financial resources.

On the other hand, the growth of total financings by Indonesian Islamic banking has reached 50.56 percent as at August 2011. As such, Islamic banks are expected to maintain sustainable capital that is capable of absorbing potential losses that emanated from any unfavorable macroeconomic conditions. Since the central bank policy encourages Islamic financial institutions to invest in the real sector, Islamic banks also face credit default risk.

The present study is therefore aimed at assessing and capturing the susceptibility of Islamic financing quality towards the changes in key macroeconomic variables.

Hence, this paper is structured as follow: the introductory part is presented in the first section while the second section provides the literature review. The third section explains the methodology while introduces the variables and data used in the paper. The empirical results are provided in section four. Finally, the fifth section concludes this study.

\section{Literature review}

\subsection{Banking Stability}

The synchronization between monetary and financial stability is really crucial to the economy. Through various channels of monetary transmission, stability of financial system influences the effectiveness of monetary policy in ensuring healthy economic activity and while maintaining inflation to the minimal. The fact remains that, the uncertainty surrounding global economic condition pose a serious threat on both macroeconomic stability and financial system, particularly in Indonesia which is the main focus of this study. The central bank, thus, formulates macro-prudential policy to strengthen macroeconomic and financial stability. This perhaps account for the increasing focus on macro-prudential policy (Bank Indonesia, 2011). The macro-prudential is based on the following three main principles: (1) liquidity control in the economy, especially the banking liquidity; (2) supervise the flow of foreign capital, and (3) enhance the banking intermediaries.

In accordance with the principle of financial intermediation, banks are susceptible to insolvency when the value of their asset falls short of the liabilities because of the inability of the borrowers to pay their debt (Demirguç-Kunt and Detragiache, 1998). The credit risk of banks is measured by the ratio of NonPerforming Loans (NPL) for conventional terms and Non Performing Financings (NPF) for Islamic terms. The previous systemic banking crises tremendously contributed to the weaknesses of the financial system, which hitherto took a dramatic negative toll on the NPL or NPF ratios. Using the macro-prudential surveillance, the assessment of overall asset quality and credit risk in banking sector becomes an important element in identifying the vulnerability in the financial sector (Clair, 2004; Bracons, et al., 2006).

Unlike the conventional system, profit rate is employed as an intermediary instrument for Islamic banking system. This is in line with the prohibition of interest rate under Islamic principle. Consequently, the fluctuation of NPF in Islamic banks might send faster signal of potential financial crises compared to conventional banks (Adebola, et.al., 2011). There is however dearth of empirical literature that explore the relationship between NPF and macroeconomic condition. This study, therefore, tries to fill this lacuna in 
the literature by examining the impact of macro-prudential concept of financing risk on the financial stability indicators of Islamic banking.

\subsection{Review of Previous Studies}

Several studies had attempted to examine the influencing factors to banks' probability of bank failure. One of these studies is Babouček and Jančar (2005) who empirically investigated the transmission of macroeconomic variables as an early warning signal of the banks' loan quality in Czech. An unrestricted VAR model was employed to investigate the relationship between macroeconomic variables and the NPL ratio. The outcome of the stress test suggests that, loan portfolio on an aggregate level has been able to absorb macroeconomic shocks without endangering the banking sector's capital base.

Gunsel (2008) investigated bank fragility from both the macro perspective and the microeconomic factors. The banks' fragility was determined using some bank specific variables (CAMELS criteria), macroeconomic variables, financial variables, and external conditions. The results confirmed that bank fragility in North Cyprus was mainly influenced by micro and macro factors. Their study however failed to elaborate on their model regarding how transmission of monetary policy indicator.

Khemraj and Pasha (2009) examined the relationship between NPL and macroeconomic with bank specific variables for the case of Guyana using a panel data set. NPL ratio has been found to be related to bank failures and financial crises in all countries. Similarly, it is indicated that, the real effective exchange rate has a significant positive impact on the NPL. While an inverse relationship has been reported between GDP growth and NPL ratio, the finding has shown that, inflation is not an important determinant of NPL in Guyana. In addition, it is stated that, banks that charges relatively higher real interest rates, tend to have higher NPL.

In the Islamic banking system, there are two notable empirical studies that analyzed the determinants of NPF. Applying for the case of Indonesia, Imaddudin (2007) compared the performance of Islamic and conventional system in relation to credit default management. This study employed ordinary least square method using 40 monthly data observation from January 2003 until April 2006. In this study, there are six dependent variables namely: total assets, total amount of third party's funds, total loans, proxy for Islamic interbank money market, GDP growth, and manufacturing industrial index. Their finding suggested that, the conventional banking has a better performance compared to the Islamic banking.

Adebola, et al. (2011) explored the determining factors for the NPF in Malaysia from 2007 to 2009. Some macroeconomic variables such as industrial production index, interest rate, and producer price were employed using ARDL approach. The findings indicated that, interest rate has significant positive long run impact on NPF of Islamic banking. It is believed that, Islamic banking system in Malaysia employ less of profit and loss mechanism since the interest rate has been found to be relatively stronger to productivity.

This estimation study obviously requires the inclusion of macroeconomic and financial variables considering its theoretical and empirical links with credit risk. Some macroeconomic variables used in this study includes, economic growth, inflation rate, ratio of M2, real exchange rate and terms of trade (Demirguc-Kunt and Detrigiache, 1998; Babouček and Jančar, 2005; Gunsel, 2008; Khemraj and Pasha, 2009). In particular, Clair (2004) and Adebola, et al. (2011) argued that interest rates are crucial variable, as they represent the direct cost of borrowing.

\section{Data and Methodology}

Time series in the form of monthly data spanning the period of October 2005 until May 2012 is used. All real data are taken and transformed into natural logarithms except for NPF rate and the Islamic Interbank Money Market (PUAS). The fluctuated volatility of those variables in specific period will reflect the relative volatility toward the volatility in other periods (Muthohharoh, 2010).

Although the sample period includes the 2008 financial crisis, this study has indicated that, Islamic banks are not severely affected by the global financial crisis. This finding is similar to that of Bank Indonesia (2009) regarding economic performance in Indonesia. During the crisis period, the performance of relevant indicators continued to improve and support real sector financing, as indicated by high asset growth, fund accumulation and financing. Some of the factors that influenced the strong growth in Islamic banks includes: high domestic demand, low integration between Islamic banks and the global financial 
system, and the reasonable level of transaction sophistication. Moreover, the impressive intermediation function of Islamic banks in Indonesia has been reflected by the declining Non Performing Financing (NPF) and increasing capital adequacy ratio. With an estimated growth of about 4.5 percent in 2009, Indonesia is one of a few countries that have been sustainably maintaining positive growth. According to Park et al. (2010) who investigate the post-crisis performance of the output gap in emerging East Asian countries, the result of the Markov-switching model suggested negative output gaps for majority of the region's economies with the exception of Indonesia that witnessed sustainable positive output gaps. Table 1 depicts the variables used in this study and the sources.

Table 1. Variables and Sources of the Data

\begin{tabular}{clll}
\hline No. & Variable & Symbol & Sources \\
\hline 1. & Non Performing Financing & $N P F$ & Central Bank of Indonesia \\
2. & Quasi Money & $L N_{-} M 2$ & Central Bank of Indonesia \\
3. & Real Exchange Rate & $L N_{-} R E R$ & Central Bank of Indonesia \\
4. & Islamic Interbank Money Market & $P U A S$ & Central Bank of Indonesia \\
5. & Consumer Price Index & $L N_{-} C P I$ & International Monetary Fund \\
6. & Industrial Production Index & $L N_{-} I P I$ & CEIC Asia Database \\
\hline
\end{tabular}

\subsection{NPF as Endogenous Variable}

Credit (default) risk remains the main source of risk in our contemporary financial systems. The probability of bank default increases when credit risk indicates higher level of risk (Imbierowicz and Rauch, 2012). NPL or NPF has been widely employed as an indicator of credit quality in conventional and Islamic banks respectively. This thus account for the mushroom of empirical studies that aims at analyzing the probability of default risk (Demirguc-Kunt and Detrigiache, 1998; Babouček and Jančar, 2005; Imaddudin, 2007; Gunsel, 2008; Khemraj and Pasha, 2009). The econometric model linking NPL with macroeconomic indicators could be relevant to policy makers. NPL is an important element of macroprudential surveillance based on the its role in identifying key vulnerabilities of the financial sector and restoring confidence in the financial sector (Beck, Jakubik, and Piloiu, 2013). Furthermore, majority of bank failures and financial crises in all countries are one way or the other related to the performance of NPF ratio (Khemraj and Pasha, 2009).

As indicated by Adebola et. al. (2011), the performance of NPF in Islamic banking may transfer financial crises signal faster than conventional banks. Thus, banking institutions should consciously conduct credit risk assessment in Islamic banks from time to time. The outcome of this study may identify possible events or future changes in economic conditions that may have unfavorable effects on the Islamic banking institutions by focusing on the performance of NPF as an endogenous variable.

\subsection{Explanatory Variables}

The explanatory variables capture many of the suggested theory that employed the ratio of nonperforming loans (Demirguc-Kunt and Detrigiache, 1998). It does not only involved macroeconomic variables but also the external condition of the economy in general and financial factors in particular. To begin with, some macroeconomic variables can be integrated to build a model regarding the performance of banks, namely the growth rate of GDP (Khemraj and Pasha, 2009), the real exchange rate (Babouček and Jančar, 2005; Gunsel, 2008), and the inflation rate (Gunsel, 2008). Secondly, the ratio of M2 to foreign exchange reserve (Demirguc-Kunt and Detrigiache, 1998; Gunsel, 2008) and Islamic interbank call money rate (Immaddudin, 2007) will represent the financial characteristics.

\subsubsection{The Growth Rate}

Mankiw (2003) states that one of the macroeconomic variables to measure economic performance is Gross Domestic Product (GDP) and it is divided into nominal GDP and real GDP. GDP measures the total 
final goods and services that represent a country's economic growth. Another economic indicator that measures real production output is the Industrial Production Index (IPI). According to Linda (2007), IPI is more exhaustive compared to GDP in explaining economic growth in monthly basis. Index of industrial production is based on value-added concepts. It covers the physical output of all stages of production in the manufacturing, mining, gas, and electric utility industries (McGuckin, 2000). This index historically represent majority of the fluctuations in total output, albeit the value added of the industrial sector is only a part of the total economy. Hence, the changes in this indicator generally reflect similar changes in overall economic activity or, indicate changes in GDP.

Through bank lending channel which serves as an investment channel for banks, credit expansion supports for the economic growth and positively affects loan portfolio quality (Babouček and Jančar, 2005). Gunsel (2008) stated that the economic growth rate is an important factor of banking distress. An increase in the growth rate is negatively linked to the possibility of credit default (Demirguc-Kunt and Detrigiache, 1998; Gunsel, 2008).

\subsubsection{The Real Exchange Rate}

The exchange rate is defined as the relative price of a local currency against other currencies (Bank Indonesia, 2004). The exchange rate is an important factor that must be considered in the open economy (Kassim et.al., 2009). The exchange rate is equally divided into two types namely: namely the nominal exchange rate and the real exchange rate. The real exchange rate is highly relevant to measure the competitiveness of an economy (Moosa, 2003). A stable exchange rate enhances the profitability of stakeholders in relation to export or import related transaction. According to Mankiw (2003), high real exchange (depreciation) influences the foreign goods to become relatively more expensive while causes domestic goods become relatively cheaper.

Real Exchange Rate (RER) also affects the performance of the bank. Several previous studies showed a negative relationship between the depreciation of the domestic currency and the loans' quality. Depreciation of the domestic currency raises the risk and reduces bank profitability due to a higher NPL (Demirguc-Kunt and Detrigiache, 1998; Gunsel, 2008).

\subsubsection{The Inflation Rate}

The most common method used to measure the rate of inflation is the Consumer Price Index (CPI). The increase in CPI indicates inflation condition that negatively affects the banking deposits (Yusoff, et al., 2008).

Muthohharoh (2010) identified two main sources of inflation namely, the demand side and supply side. If the central bank implements an expansionary monetary policy, the firms and household might experience losses because of the demand inflation. Based on the fact that, inflation resulting from the changes in money supply cannot be controlled by companies and households, the ability to meet their credit obligation reduce fall which consequently result to increase in NPL and NPF. Conversely, if the inflation occurs from the supply side, it will reduce the level of NPL and NPF. Hence, companies have higher incentive to repay the bank financing due to enabling environment that helps in boosting their revenue through increase in the price of goods. Indeed, cost arising from the supply side constitutes a significant source of inflation in Indonesia. As such, it is assumed that an increase in inflation could lead to a decline in the NPF ratio.

\subsubsection{Quasi Money (M2)}

The changes in money supply could be linked to changes in interest rates, price levels, and ultimately affect economic activity, which then affect the quality of bank loans. Some of the previous empirical studies stated that, there is a positive relationship between money supply and likelihood of bank failure which is measured by non-performing loans (Babouček and Jančar, 2005; Gunsel, 2008). An increase in money supply leads to increase in inflation. To control inflation, the monetary authorities try to absorb money supply by raising interest rates which in turn cause the debtors to ultimately fail to fulfill their credit obligation to the bank (Muthohharoh, 2010). 


\subsubsection{Islamic Interbank Call Money Rate}

The demand and supply of short term credit generally happen because of two main reasons (Rosly, 2005). Firstly, money market is designed to meet short term loans of corporations, financial, institutions and government. Secondly, money market serves to meet short-term investment. It is applied on the basis of Shari'ah principles derived from the Qur'an, Sunnah and legal opinions of the Islamic jurist by means of ijma (consensus), qiyas (analogy) and ijtihad (independent thinking). The prohibition of riba, the requirement of 'iwad (risk-taking and value-addition), and the avoidance of gharar (uncertainty) are three main principles to perform the basis of Islamic money market operation.

One of the most important instruments of monetary operation and money market transaction in Indonesia is Islamic Interbank Money Market (PUAS). As stated by bank Indonesia (2013), Islamic Interbank Money Market (PUAS) is a short-term financial transaction among banks conducting business based on either the rupiah or foreign currency in accordance with the principles of Islamic. The instrument of Islamic Interbank Money Market Market (PUAS) is based on the Interbank Mudaraba Investment Agreement (IMA) Certificate. Imaduddin (2007) showed that, Islamic interbank money market does not significantly influence the NPF ratio in Islamic banking.

\subsection{Framework of The Analysis}

Monetary stability, macroeconomic condition, and banking stability are three major sectors that are inter-connected. There are two main approaches to translating macroeconomic shocks in the financial sector variables (Cihák, 2007). Firstly, the bottom-up approach, whereby the impact is estimated using data on individual portfolios. Secondly, the top-down approach, where the impact is estimated using aggregated data. Since it is hampered by insufficient data and calculation complexities, this study will use a top-down approach by combining the macroprudential stress tests. The advantage of this approach is that, it is capable of providing a more detailed modeling and use a wider set of data. It is assumed that financings quality is sensitive to the economic cycle.

\subsection{Method of Estimation}

Time series analysis aims to explain patterns or behavioral data throughout the period of observation and forecasting. This study employs multivariate time series analysis that is based on Vector Auto Regression (VAR). There are several steps that need to be done which are unit root test, stability VAR test, the optimal lag, cointegration test, the long run model based on a vector error correction framework, and innovation accounting consisting of analysis of the Impulse Response Function (IRF) and Variance Decomposition (VD).

\subsubsection{Unit Root Test.}

In time series analysis, the stationary of variables is very important in order to avoid a spurious regression in the model. The data is stationary when there is a constant pattern over time or inclination fluctuating around the average value (Gujarati, 2009). Although there are several tests of stationary among which are Augmented Dickey Fuller (ADF) test. This test is conducted by "augmenting" the form of a random walk with drift by adding the lagged values of the dependent variable $\Delta$ Yt (Gujarati, 2009). The $\mathrm{ADF}$ test will be estimated on following regression:

$$
\Delta Y_{t}=\beta_{1}+\beta_{2} t+\delta Y_{t-1}+\alpha_{i} \Sigma_{i=1}^{m} Y_{t-1}+\varepsilon_{t}
$$

Where $\beta_{1}$ and $\beta_{2}$ are parameters, $\mathrm{t}$ is the time or trend variable, $\delta$ represents drift, $\varepsilon_{t}$ is a pure white noise error term and $\Delta Y_{t-1}=\left(Y_{t-1}-Y_{t-2}\right), \Delta Y_{t-2}=\left(Y_{t-2}-Y_{t-3}\right)$, etc. If value of the ADF test statistics is less than the MacKinnon critical value then rejecting a null hypothesis $(\delta<0)$ which means that the data is stationary. If the null hypothesis exist $(\delta=0)$ then there is a unit root or non-stationary.

\subsubsection{Determination of Optimal Lag}

In economics, the dependence of a dependent variable on another explanatory variable is rarely instantaneous or responding with a lapse of time. Such a lapse of time is called a lag (Gujarati, 2009). The 
distributed-lag models, thus, plays a highly significant role in economics. There are two general steps to follow before deciding the right lag in VAR model.

Firstly, find the maximum lag on the VAR stability that is based on the roots of the characteristic polynomial. VAR satisfies the stability condition if the value of its AR roots is less than one and there is no root that lies outside the unit circle (Gujarati, 2003). If there is unstable VAR, the results of impulse response function and variance decomposition will not be valid (Ascarya, 2009).

Secondly, the optimal lag length will be chosen by using the available criteria information. Determination of the optimal lag can be identified using one of two criteria, namely the Likelihood Ratio (LR), Final Prediction Error (FPE), Akaike Information Criterion (AIC), Schwarz Information Criterion (SIC) and Hannan-Quin Criterion (HQ). Where $|\Sigma|$ is the determinant of the covariance matrix or the residual variance, and $\mathrm{N}$ is the total of the estimated parameters, the calculation of AIC and SC can be written on the following equation (Enders, 1995):

$$
\begin{aligned}
& A I C=T \log |\Sigma|+2 N \\
& S C=T \log |\Sigma|+N \log (T)
\end{aligned}
$$

\subsubsection{Cointegration Test}

Cointegration is a long-term relationship between variables that are individually non-stationary, but there is a possibility that these linear combinations between these variables can cancel out the stochastic trend in the two series so that be stationary (Gujarati, 2009). A number of methods for testing cointegration have been proposed in the literature. This study considers the simple method of Johansen cointegration test that can be shown as follows:

$$
\Delta Y_{t}=\beta_{0}+\pi Y_{t-1}+\sum_{i=1}^{p} \Gamma \Delta Y_{t-1}+\varepsilon_{t}
$$

The component of vector $Y t$ is cointegrated if the vector of $\beta=\left(\beta_{1}, \beta_{2}, \ldots \beta_{n}\right)$ so that this combination $\beta Y t$ is stationary. Vector $\beta$ is called as cointegration vector. If the trace statistics greater than MacKinnon Critical value then $H_{0}$ is rejected. It means that the equation has cointegration relations.

\subsubsection{Vector Autoregression (VAR) Analysis}

A structural approach commonly uses economic theory while trying to describe the relationship amongst the variables that will be tested. In some cases, it is not sufficient to provide a specific dynamic relation amongst these variables. Vector Autoregression (VAR) emerges as a solution in utilizing structural approach for simultaneous model. It is a form of modeling that is commonly utilized for the multivariate time series analysis. VAR model includes the selection of variables and a lot of lag in the model. The VAR method has several advantages according to Gujarati (2009), namely:

1. VAR method and its estimation are simple because there is no need to distinguish both exogenous and endogenous variables.

2. In many cases, the forecasts in this method are better than those from the more complex simultaneous-equation method.

On the other side, Gujarati (2009) explains that the VAR method also has several problems, such as:

1. VAR model is a-theoretic because it uses less prior information.

2. The toughest challenge in the VAR model is the selection of the appropriate lag length.

3. The coefficient in the estimated VAR is difficult to interpret

4. VAR models are less suited for policy analysis because of its emphasis on forecasting.

\subsubsection{Innovation Accounting}

The innovation accounting aims to test dynamic structure from the variable system in the model that is represented by innovation variable. There are two methods used in describing the innovation accounting, namely the Impulse Response Function (IRF) and Variance Decomposition (VD). 
Firstly, the Impulse Response Function (IRF) analysis is a method used to determine the response of the endogenous variables to the shock from a particular variable. It also helps in knowing how long these effects occur. Gujarati (2009) indicated that, it is not always easy if there are several lags in each equation, thus the Impulse Response Function (IRF) in VAR modeling finds out how the dependent variable responds to a shock administrated to one or more equations in the system. Shocks are determined by the changes in the one standard deviation of error term that would be responded by the dependent variable in the present and the future. This technique is very useful for certain policies and sensitivity analysis (Sugema and Chowdhury, 2005).

Secondly, the Variance Decomposition (VD) is use to calculate and analyze the influence of random shocks of certain variables on the endogenous variables. This method generates information about the composition of variables that are relatively more important in determining the endogenous variable. Moreover, it analyzes the changes in the variable indicated by the error variance from other variables. In this study variance decomposition presents the innovation value from the variables of M2, RER, PUAS, CPI, and IPI in determining Non Performing Financings (NPF).

\subsection{Model of Research}

The equation of VAR model in matrix for non-performing financings can be written as follows:

$$
\left[\begin{array}{l}
N P F_{t} \\
L N_{-} R E R_{t} \\
L N_{-} C P I_{t} \\
P U A S_{t} \\
L N_{-} I P I_{t} \\
L N_{-} M 2_{t}
\end{array}\right]=\left[\begin{array}{l}
a_{10} \\
a_{20} \\
a_{30} \\
a_{40} \\
a_{50} \\
a_{60}
\end{array}\right]+\left[\begin{array}{llllll}
a_{11} & a_{12} & a_{13} & a_{14} & a_{15} & a_{16} \\
a_{21} & a_{22} & a_{33} & a_{24} & a_{25} & a_{26} \\
a_{31} & a_{32} & a_{33} & a_{34} & a_{35} & a_{36} \\
a_{41} & a_{42} & a_{43} & a_{44} & a_{45} & a_{46} \\
a_{51} & a_{52} & a_{53} & a_{54} & a_{55} & a_{56} \\
a_{61} & a_{62} & a_{63} & a_{64} & a_{65} & a_{67}
\end{array}\right]\left[\begin{array}{l}
N P F_{t-n} \\
L N_{-} R E R_{t-n} \\
L N_{-} C P I_{t-n} \\
P U A S_{t-n} \\
L N_{-} I P I_{t-n} \\
L N_{-} M 2_{t-n}
\end{array}\right]+\left[\begin{array}{l}
\varepsilon_{1 t} \\
\varepsilon_{2 t} \\
\varepsilon_{3 t} \\
\varepsilon_{4 t} \\
\varepsilon_{5 t} \\
\varepsilon_{6 t}
\end{array}\right]
$$

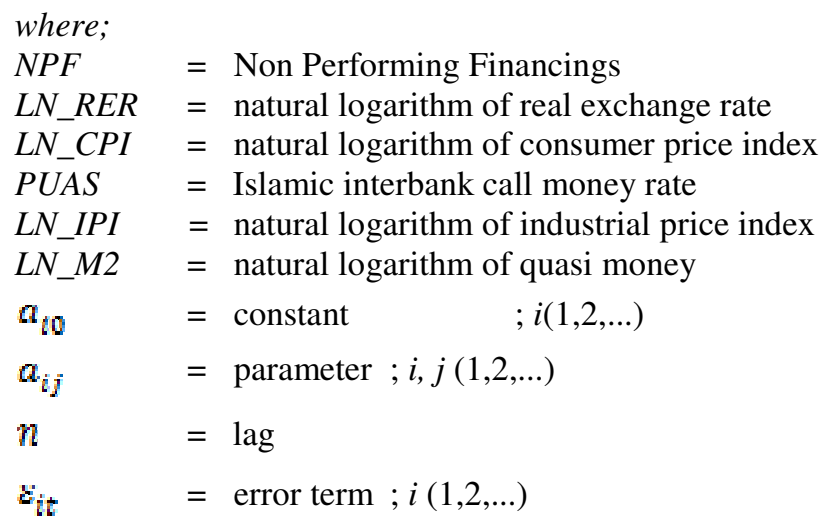

\section{Findings and Discussion}

\subsection{Unit Root Tests}

Tests of unit roots in this study are based on the ADF test (Augmented Dickey Fuller) and PhillipPerron test. Table 2 shows the result of stationary test of NPF model. All variables are not stationary at level; hence unit root tests must be conducted at the first level of difference. It is found that all those variables become stationary on the degree of integration one.

Table 2. Unit Root Test

\begin{tabular}{lllll}
\hline & \multicolumn{3}{c}{ ADF } & PP \\
\cline { 2 - 4 } Variable & Level & $1^{\text {st }}$ Difference & Level & $1^{\text {st }}$ Difference \\
& & & & \\
\hline
\end{tabular}




\begin{tabular}{ccccc}
\hline NPF & -2.0191 & $-10.7548 * * *$ & -1.8464 & $-11.1011 * * *$ \\
LN_RER & -2.7758 & $-8.4795^{* * *}$ & -2.8450 & $-8.4325 * * *$ \\
LN_CPI & -0.9813 & $-8.5447 * * *$ & -1.1067 & $-8.5447 * * *$ \\
PUAS & -3.0315 & $-12.7307 * * *$ & -2.8395 & $-23.3539 * * *$ \\
LN_IPI & -1.1770 & $-15.5709 * * *$ & -1.4771 & $-16.6929 * * *$ \\
LN_M2 & -2.6193 & $-9.2861 * * *$ & -2.2886 & $-12.6556 * * *$ \\
\hline Note: *** significant at 1\% alpha; $* *$ significant at 5\% alpha; $*$ significant at $10 \%$ alpha.
\end{tabular}

\subsection{Selection of Optimal Lag}

Optimal lags length need to be applied to overcome the problem of autocorrelation (Ascarya, 2009). Moreover, determination of optimal lag length is very important because the lag of the endogenous variables will be used as an exogenous variable in the system (Enders, 1995). The selection of optimal lag in this study is based on the shortest lag of Akaike Information Criterion (AIC), Schwarz Information Criterion (SIC) and Hannan-Quin Criterion (HQ). Table 3 shows the result of optimal lag selection test for NPF model. Based on AIC, lag order selected based on the criterion for NPF model is 2 . However, based on SC and HQ, lag order selected by the criterion for NPF model is 1 . Thus, the lag order selected in this study is 1 .

Table 3. Optimal Lag

\begin{tabular}{cccc}
\hline \hline Lag & AIC & SC & HQ \\
\hline \hline 0 & -4.529537 & -4.370277 & -4.465140 \\
1 & -17.02325 & $-15.90842^{*}$ & $-16.57247^{*}$ \\
2 & $-17.04671^{*}$ & -14.97632 & -16.20954 \\
3 & -16.79008 & -13.76413 & -15.56654 \\
4 & -16.57856 & -12.59705 & -14.96863 \\
\hline \hline
\end{tabular}

Note: *indicates lag order selected by the criterion.

\subsection{Cointegration Test}

All variables are generally stationary at first difference, so that contegration test based on trace statistics will be applied to determine the number of cointegration rank that can explain a long-term relationship. Table 4 shows the result of cointegration test for NPF model. The Trace test of this model indicates one cointegrating equation at the 5 percent critical value. However, for a small sample analysis, Reinsel and Ahn (1992) suggested an adjustment to the estimated trace statistics. The degree-of-freedom correction suggested by Reinsel and Ahn (1992) is to multiply the computed trace statistic by (T-pk)/T, where T is the sample size, $\mathrm{p}$ is the number of variables, and $\mathrm{k}$ is the lag length of the estimated VAR system. In the analysis that follows, we relied on the Reinsel and Ahn suggestion to check for the significance and the robustness of the cointegration tests. Thus, there is evidence for at least one cointegration exists.

Table 4. Johansen Cointegration Test for NPF Model

\begin{tabular}{lcccc}
\hline \hline $\begin{array}{c}\text { Hypothesized } \\
\text { No. of CE(s) }\end{array}$ & Eigenvalue & $\begin{array}{c}\text { Trace } \\
\text { Statistic }\end{array}$ & $\begin{array}{c}0.05 \\
\text { Critical Value }\end{array}$ & $\begin{array}{c}\text { Reinsel-Ahn } \\
\text { Adjustment }\end{array}$ \\
\hline \hline None * & 0.375944 & 119.5798 & 95.75366 & $113.4788^{* *}$ \\
At most 1 & 0.253920 & 73.37134 & 69.81889 & 69.6279 \\
At most 2 & 0.241883 & 44.66488 & 47.85613 & 42.3861 \\
At most 3 & 0.089871 & 17.52695 & 29.79707 & 16.6327 \\
At most 4 & 0.081188 & 8.298381 & 15.49471 & 7.8750 \\
At most 5 & $3.91 \mathrm{E}-06$ & 0.000383 & 3.841466 & 0.000363 \\
\hline \hline
\end{tabular}

Note: $*$ indicates cointegrating equation(s) at $5 \%$ alpha before the adjustment. $* *$ indicates cointegrating equation(s) at $5 \%$ alpha after the adjustment. 


\subsection{Long Run Model}

Equation 6 below shows the long run relationship between the dependent and independent variables under the vector error correction framework. It can be seen that all independent variables significantly affect the NPF of Islamic banks in the long run (the number in parentheses are t-ratios).

$e c t=N P F(-1)+225.5653 \operatorname{LRER}(-1)+603.7676 \operatorname{LCPI}(-1)-21.0569 \mathrm{PUAS}(-1)+$

507.0506LIPI(-1) - 632.4247LM2(-1) - 1761.601

Similar to Demirguc-Kunt and Detrigiache (1998) and Gunsel (2008), this study has found a negative relationship between the depreciation of the domestic currency and the financing's quality. As a response, high real exchange (depreciation) causes the foreign goods to be relatively more expensive while make domestic goods to be relatively cheaper. Since the source of inflation in Indonesia is from the cost (supply) side (Muthohharoh, 2010), it is therefore assumed that an increase in inflation will lead to a decline in the NPF ratio. This study, however, has provided the supporting evidence of this relationship.

With regard to the economic growth, similar to Demirguc-Kunt and Detrigiache (1998) and Gunsel (2008), this study also found that economic growth negatively affecting the bad loans probability. Meanwhile, the long run relationship between money supply and bad loans is shown to be positive. This finding is in line with that of Babouček and Jančar (2005) and Gunsel (2008). Lastly, unlike Imaduddin (2007), this study found that Islamic interbank money market rate is positively affecting the probability of non performing financing.

\subsection{Impulse Response Function (IRF) Analysis}

Various modelling techniques have been applied to estimate the credit risk model. One of these approaches is based on data of loan performance in aggregate level, such as NPL (Cihák, 2007). In the identification methods, the NPL is assumed to be endogenous to the other macroeconomic variables. The Impulse Response Function (IRF) explains the sensitivity of NPL to the shocks of the macroeconomic variables.

Table 5. Impulse Response Function Summary

\begin{tabular}{ll}
\hline SHOCK & RESPONSE OF NPF \\
\hline LN_RER & Negative and permanent at 0.065, stabilize in $8^{\text {th }}$ period \\
LN_CPI & Negative and permanent at 0.058, stabilize in $7^{\text {th }}$ period \\
PUAS & Positive and permanent at 0.097, stabilize in $8^{\text {th }}$ period \\
LN_IPI & Negative and permanent at 0.018, stabilize in $8^{\text {th }}$ period \\
LN_M2 & Positive and permanent at 0.129, stabilize in $8^{\text {th }}$ period \\
\hline
\end{tabular}

Impulse response analysis is particularly helpful in addressing specific risk-management and producing a rank order of the possible shock scenarios (Fogail, 2009). This approach also has a threefold purposes (Babouček and Jančar, 2005). The first purpose is to create a forecast of the quality of the banking sector's loan portfolio. Secondly, to determine the macroeconomic factors that can influence the quality of the loan. Finally, to perform stress tests by measuring the banking sector's vulnerability to credit risk on a macroeconomic level.

Table 5 summarizes information from Figure 1 which shows that sensitivity's direction of NPF towards the tested macroeconomic variables are all similar to what has been shown by the long run equation under the vector error correction framework. One standard deviation shock of exchange rate leads to a decrease in default ratio (NPF) of Islamic banks. In relation to the case of Indonesia, depreciation of currency value could potentially influence the changes in capital goods which are mostly imported from foreign countries. 
Majority of the export based industries and infrastructure investments strictly dependent on imported tools and machinery. When import prices increase, it will impact on the ability of the companies in paying back their loan to the bank.

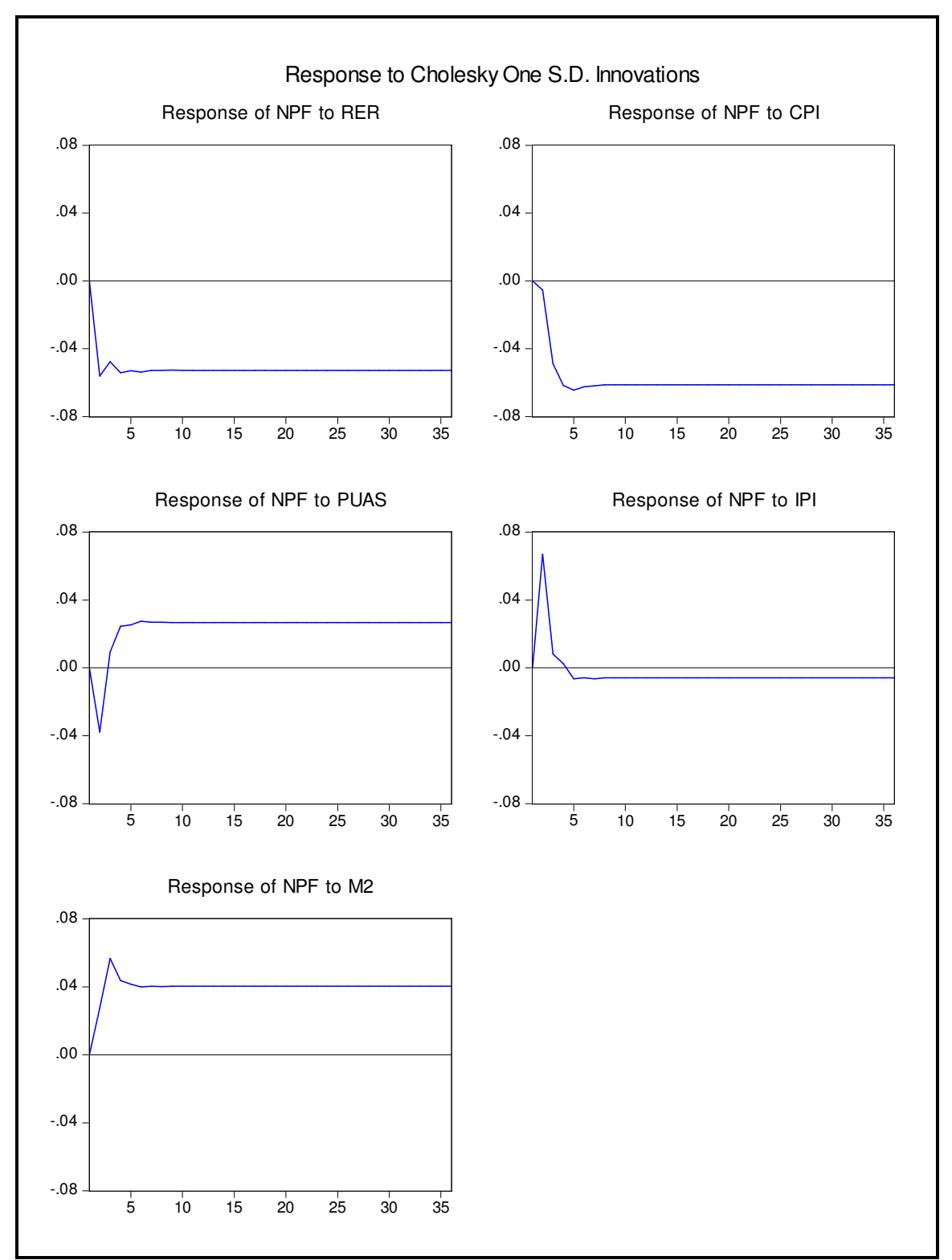

Figure 1. Impulse Response Function Graphs

The shock of Consumer Price Index (CPI) depicts the negative response of NPF. Inflationary pressure from the cost side is a significant source of inflation in the price formation in Indonesia. Companies capitalized on this condition by raising the price of goods and services. This possibly could increase the company's revenue, which could consequently result to company's inability to repay the loan or bank financing. Hence, the increase NPL or NPF also decreased (Muthohharoh, 2010).

The impulse from the variable of Interbank otherwise refers to as Money Rate (PUAS) will be responded positively by NPF. This positive response has significant effect in the long term. The increase in PUAS rate leads to the increase of profit and loss share in Islamic banks. This consequently resulted to a great loss of the balance sheets of firms and households because of the higher share payment by the 
company to the bank. Ultimately, the companies and household fail to meet its obligations to the bank, so then NPF increases.

One standard deviation shock of Industrial Production Index (IPI) will be responded negatively by NPF in the long term. The better condition of economic growth reflected an increase of IPI. It leads to an increase of loan repayment capacity by companies and households, and therefore the NPF ratio in Islamic banks tends to be decreased.

NPF has positive response from the impulse of money supply (M2), meaning that the increase of money supply will cause the decrease of NPF ratio. This circumstance might occur because of the higher money supply which is positively related to the market risk faced by banks. For instance, the unanticipated depreciation of exchange rate and the higher inflation could cause company to suffer losses. At the end, the ability of firms and households to meet their payment obligations will decline. The credit quality of bank (NPF) will significantly increase in the long term (Muthohharoh, 2010). Based on these analyses, this study has identified possible events or future changes in major economic conditions that could be beneficial on the default management of Islamic banking.

Table 6. The Off-Diagonal Values of the VD Matrix

\begin{tabular}{|c|c|c|c|c|c|c|}
\hline Period & NPF & RER & CPI & PUAS & IPI & M2 \\
\hline \multicolumn{7}{|c|}{ Variance Decomposition of NPF } \\
\hline 1 & 100.00 & 0.00 & 0.00 & 0.00 & 0.00 & 0.00 \\
\hline 10 & 94.99 & 1.55 & 1.81 & 0.39 & 0.29 & 0.97 \\
\hline 19 & 94.67 & 1.66 & 2.08 & 0.42 & 0.17 & 1.00 \\
\hline 28 & 94.55 & 1.69 & 2.18 & 0.43 & 0.12 & 1.02 \\
\hline 36 & 94.49 & 1.71 & 2.23 & 0.44 & 0.10 & 1.02 \\
\hline \multicolumn{7}{|c|}{ Variance Decomposition of RER } \\
\hline 1 & 5.75 & 94.25 & 0.00 & 0.00 & 0.00 & 0.00 \\
\hline 10 & 6.00 & 88.29 & 0.40 & 3.17 & 2.11 & 0.03 \\
\hline 19 & 5.76 & 88.03 & 0.43 & 3.43 & 2.31 & 0.03 \\
\hline 28 & 5.68 & 87.94 & 0.44 & 3.53 & 2.38 & 0.03 \\
\hline 36 & 5.64 & 87.90 & 0.44 & 3.57 & 2.42 & 0.03 \\
\hline \multicolumn{7}{|c|}{ Variance Decomposition of CPI } \\
\hline 1 & 2.74 & 13.54 & 83.73 & 0.00 & 0.00 & 0.00 \\
\hline 10 & 1.64 & 3.79 & 89.23 & 0.04 & 1.48 & 3.83 \\
\hline 19 & 1.38 & 3.38 & 89.56 & 0.03 & 1.65 & 4.01 \\
\hline 28 & 1.29 & 3.24 & 89.67 & 0.03 & 1.71 & 4.07 \\
\hline 36 & 1.24 & 3.17 & 89.73 & 0.03 & 1.74 & 4.09 \\
\hline \multicolumn{7}{|c|}{ Variance Decomposition of PUAS } \\
\hline 1 & 0.00 & 0.19 & 0.32 & 99.48 & 0.00 & 0.00 \\
\hline 10 & 2.80 & 3.74 & 12.81 & 46.10 & 24.99 & 9.55 \\
\hline 19 & 3.60 & 3.95 & 15.03 & 36.87 & 30.30 & 10.25 \\
\hline 28 & 3.92 & 4.03 & 15.90 & 33.21 & 32.40 & 10.53 \\
\hline 36 & 4.07 & 4.07 & 16.33 & 31.43 & 33.43 & 10.66 \\
\hline \multicolumn{7}{|c|}{ Variance Decomposition of IPI } \\
\hline 1 & 0.26 & 0.38 & 0.06 & 0.63 & 98.68 & 0.00 \\
\hline 10 & 0.37 & 5.37 & 27.36 & 3.62 & 62.90 & 0.36 \\
\hline 19 & 0.25 & 5.48 & 30.20 & 4.18 & 59.66 & 0.22 \\
\hline
\end{tabular}




\begin{tabular}{|c|c|c|c|c|c|c|}
\hline & & & & & & \\
\hline 28 & 0.21 & 5.53 & 31.28 & 4.39 & 58.43 & 0.17 \\
\hline 36 & 0.18 & 5.55 & 31.79 & 4.49 & 57.84 & 0.15 \\
\hline \multicolumn{7}{|c|}{ Variance Decomposition of M2 } \\
\hline 1 & 15.95 & 25.62 & 9.09 & 0.35 & 0.17 & 48.82 \\
\hline 10 & 2.85 & 35.21 & 26.78 & 1.77 & 3.24 & 30.14 \\
\hline 19 & 1.89 & 35.50 & 28.08 & 1.90 & 3.63 & 29.00 \\
\hline 28 & 1.53 & 35.60 & 28.57 & 1.95 & 3.77 & 28.58 \\
\hline 36 & 1.36 & 35.65 & 28.80 & 1.97 & 3.84 & 28.38 \\
\hline
\end{tabular}

All instruments of macroeconomic variables indicated similar response of faster stability period. It is significantly proven that NPF model is stable in responding the macroeconomic shocks. Three variables that negatively drive the NPF rate of Islamic banks are exchange rate, inflation and economic growth. On the hand, two variables positively drive the NPF rate of Islamic banks which are money supply and Islamic interbank money market rate.

\subsection{Variance Decomposition (VD)}

Table 6 shows the Variance Decomposition in calculating and analyzing the influence of random shocks of macroeconomic variables upon the NPF of Islamic banks. As can be seen, there are two variables that influence NPF rate at its early stages are exchange rate and economic growth. However, the influence of growth towards the NPF rate is becoming smaller in the next periods, whilst for exchange rate is becoming larger. This shows that in the period of analysis, Islamic banks are quite concentrated on the financing using foreign currencies and ultimately culminated in shock in the exchange rate that is significantly influence the credit performance of their customers.

As indicated in table 6, the fluctuation of NPF is accounted by NPF itself with 94.49 percent. The explanatory power of other variables, which are RER, CPI, PUAS, IPI, and M2, explains a small proportion of innovations in NPF. Interestingly, started from the 3rd period, inflation and money supply show a great influence upon the susceptibility of the NPF rate and the influence remains until period 35th. This result therefore encourages regulators to monitor the overall macroeconomic condition including inflation and money circulated in the economy.

Looking along the diagonal values of the Variance Decomposition (VD), the results reveal the exogeneity of NPF, RER, and CPI. The variable of NPF is the most exogenous because its variance appears to be mostly explained by its own shock with 94.99 percent. On the other hand, the result of the variance percentage is explained by own shock for RER and CPI are relatively similar with 87.90 percent and 89.73 percent respectively. The most endogenous variable is M2 which is determined by 71.62 percent from other variable shocks.

\section{Conclusion}

This study is aimed at examining the key macroeconomic variables that influence the credit performance of Islamic banking sector with special focus on the case of Indonesia spanning the period of October 2005 until May 2012. In this study, the performance indicator is represented by NPF. The result shows that in the long run, exchange rate, supply side-inflation and economic growth are negatively related to the NPF rate. This means that, when the local currency is stronger as compared to US dollar, the supply side-inflation and economic growth increase, the NPF rate decreases, and credit risk are easily managed. On the other hand, positive influence is given by Islamic interbank money market rate and money supply upon the NPF rate which shows that the increase in those variables will increase the NPF rate, and eventually creates credit risk for Islamic banks.

Some limitations have been identified in this study are: (i) this study did not include bank specific indicators which are also believed to have significant impact on the NPF rate; (ii) the period analyzed is only seven years. As such, the following suggestions for future researches are identified: (i) future could 
incorporate bank specific indicators as the predictors and (ii) future study could also use longer period so as to produce a more robust result.

\section{References}

Ascarya,(2009)."Lesson Learned from Repeated Financial Crises: An Islamic Economic Perspective." Bulletin of Monetary Economics and Banking, Bank Indonesia.

Adebola, S. S., W. S. W. Yusoff, and J. Dahlan.(2011)."An Ardl Approach to The Determinants of NonPerforming Loans In Islamic Banking System In Malaysia." Kuwait Chapter of Arabian Journal of Business and Management Review. 1(2), 20-30.

Bacha, O. I.(2004)."Dual Banking Systems and Interest Rate Risk for Islamic Banks".MPRA Paper, No 12763.

Babouček, I. and M. Jančar.(2005)."Effects of Macroeconomic Shocks to the Quality of the Aggregate Loan Portfolio." CNB Working Paper Series, 1.

Banjarnahor, N. R.(2008)."Mekanisme Suku Bunga SBI sebagai Sasaran Opersional Kebijakan Moneter dan Variabel Makroekonomi Indonesia: 1990.1-2007.4." Bulletin of Monetary Economics and Banking, 11(1).

Bank Indonesia. "Annual Economic Report on Indonesia." Various Issues. Jakarta, Indonesia.

Basri, M. C.(2002). "Why Tre ds of Protection Changed Over Time in Indonesia." ISEAS Visiting Researchers Series No. 2.

Beck, R., P. Jakubik, and A. Piloiu. (2013). "Non-Performing Loans: What Matters in Addition to the Economic Cycle?" The European Central Bank Working Paper Series, no. 1515.

Bracons, A. O., Charles A. E. G., Dimitrios P. T., and Lea Z.(2006)."Towards a Measure of Financial Fragility." Discussion Paper Series. 554(2).

Cihák. (2007). "Introduction to Applied Stress Testing." IMF Working Paper, 59.

Clair, R. St.(2004)."Macroeconomic Determinants of Banking Financial Performance and Resilience in Singapore." Monetary Autharity of Singapore Staff Paper. Pp (38).

Demirguç-Kunt, A. and E. Detragiache.(1998). "The Determinants of Banking Crises in Developing and Developed Countries." IMF Staff Paper, 45(1).

Drehman, M., A. J. Patton, and S. Sorensen. (2006). Non Linearity and Stress Testing. Bank of England, London.

Dendawijaya, L. (2001). Manajemen Perbankan. Ghalia Indonesia, Jakarta.

Enders, Walters. (1995). Applied Econometrics Time Series. John Wiley and Sons, inc., Canada.

Endresz, M. V. and Z. Vasary.(2008)."Macro Stress Testing with Sector Specific Bankruptcy Models." MNB Working Papers.

Foglia, A.(2009). "Stress Testing Credit Risk: A Survey of Authorities' Approaches." International Journal of Central Banking, 5(3).

Graeve, F., T. Kick, and M. Koetter. (2008)."Monetary Policy and Bank Distress: An Integrated Micro and Macro Approach." Discussion Paper Banking and Financial Studies. 2(3).

Gujarati, D. N. and Dawn C. Porter. (2009). Basic Econometrics Fifth Edition. New York: McGraw-Hill.

Hoggarth, G., S. Sorensen, and L. Zicchino.(2005.) "Stress Testing of UK banks using a VAR Approach." Bank of England Working Paper. 282.

Gunsel, Nil.(2008). "Micro and Macro Determinants of Bank Fragility in North Cyprus Economy." International Research Journal of Finance and Economics. Vol. 22. Euro Journals Publishing, Inc.

Imaduddin, M. (2007). Determinants of Banking Credit Default in Indonesia: A Comparative Analysis.

Imbierowicz, B. and C. Rauch. (2012). The Relationship between Liquidity Risk and Credit Risk in Banks. Goethe University Frankfurt, Germany.

International Monetary Fund. (2011). "Russian Federation: Technical Note on Stress Testing of the Banking Sector." IMF Country Report, 11(334).

Islamic Financial Service Board. (2012) . Guiding Principle on Stress Testing For Institutions Offering Islamic Financial Services. Kuala Lumpur, IFSB.

Kassim, S. H., M. S. A. Majid, and R. M. Yusof. (2009). "Impact of Monetary Policy Shocks on The Conventional and Islamic Banks In a Dual Banking System : Evidence from Malaysia." Journal of Economic Cooperation and Development, 30(1): 41-58. 
Kearns, A.(2004). "Loan Losses and the Macro economy: A Framework for Stress Testing Credit Institutions' Financial Well-Being." Financial Stability Report. Pp 111-122.

Khemraj, T. and S. Pasha.(2009)."The Determinants of Non-Performing Loans: an Econometric Case Study of Guyana." Paper Presented at the Caribbean Centre for Banking and Finance Biannual Conference on Banking and Finance, Trinidad.

Linda, M.(2007). Responsifitas Kredit Investasi terhadap Variabel Makro ekonomi dan Perbankan Pada Bank Persero dan Bank Umum Swasta Nasional Devisa dan Non Devisa. Faculty of Economics and Management. Bogor Agricultural University, Bogor.

Lucas R. E. jr.(1976). Econometric Policy Evaluation: a Critique. Carnegie-Rochester Conference Series on Public Policy, 1, 19-46.

Mankiw, N. G. (2003). Teori Makro ekonomi. Erlangga, Jakarta.

Ibrahim, M. H. (2011)."Stock Market Development and Macroeconomic Performance in Thailand." Engineering Economics Paper, 22(3): 230-240.

McGuckin, R. H. (2000). Business Cycle Indicators Handbook. United States. The Conference Board, United States.

Mishkin, F. S. (1998). The Economics of Money, Banking, and Financial Market. Fifth Edition. Addison Wesley, Massachusetts.

Moosa, I. A. (2003). International Finance. 2nd Edition. McGraw Hill, New York.

Muthohharoh, M. (2010). The Impact of Macroeconomic Shocks on Stability of Dual Banking System in Indonesia. Faculty of Economics and Management. Bogor Agricultural University, Bogor.

Nursechafia. (2010). The Impact of Macroeconomic Shocks on Deposits and Credit in a Dual banking System in Indonesia. Faculty of Economics and Management. Bogor Agricultural University, Bogor.

Park, C., R. P. Majuca, and J. T. Yap. (2010)."The 2008 Financial Crisis and Potential Output in Asia: Impact and Policy Implications." The Philippine Institute for Development Studies (PIDS) Discussion Paper Series, no. 11.

Pesaran, M. H., T. Schuermann, B.-J. Treutler, and S. M. Weiner. (2006). "Macroeconomic Dynamics and Credit Risk: A Global Perspective." Journal of Money, Credit, and Banking, .38 (5): 1211-61.

Reinsal, G. C., and Ahn, S. K. (1992)."Vector Autoregression Models with Unit Root and Reduced Rank Structure: Estimation, Likelihood Ratio Test, and Forecasting." Journal of Time Series Analysis, 13, 353-375.

Rosly, S. A. 2005. Critical Issues on Islamic Banking and Financial Markets: Islamic Economics, Banking and Finance, Investments, Takaful, and Financial Planning. Kuala Lumpur: Dinamas Publishing.

Schechtman, R. and Gaglianone, W. P.(2011)."Macro Stress Testing of Credit Risk Focused on the Tails." The Banco Central do Brasil Working Paper, 241.

Sugema, I. and A. Chowdury.(2007)."Has Aid Made the Government of Indonesia Lazy?".Asia-Pacific Development Journal. 14(1).

Yusof, R.M., M. Wosabi, and M. S. A. Majid. (2008)."Monetary Policy Shocks and Islamic Banks Deposits in a Dual Banking System: A Comparative Analysis Between Malaysia and Bahrain." $8^{\text {th }}$ Global Conference on Business and Economics. 